\title{
A STUDY TO INVESTIGATE THE PREVALENCE OF METABOLIC AND METABOLIC LIKE SYNDROME IN STABLE COPD PATIENTS
}

\author{
Dr Sachin Kumar \\ Gupta \\ Senior Resident Dept Of Respiratory Medicine, IRD, SMS Medical College, \\ Jaipur
}

Dr Aashish Kumar Singh*

Assoc Prof Dept Of Respiratory Medicine, IRD, SMS Medical College, Jaipur ${ }^{*}$ Corresponding Author

\section{Dr Amit Singh}

Meena

\section{Dr Ankita Bajpai}

ABSTRACT BACKGROUND: Chronic Obstructive Pulmonary Disease (COPD) is associated with several extrapulmonary systemic manifestations including metabolic and metabolic like syndrome. The objective of study was to assess prevalence of metabolic like syndrome among COPD patients.

METHODS: This study was conducted from April 2017 to March 2018. Total 67 COPD patients were classified according to GOLD guideline. International Diabetes Federation (IDF) guideline was used for metabolic syndrome(MetS).

RESULTS: Prevalence of MetS was 29.85\%, highest (47.06\%) in GOLD stage-II. If central obesity was excluded than prevalence of metabolic like syndrome was $55.27 \%$, highest $(70 \%$ ) in stage-IV .

CONCLUSIONS: MetS is missed in advance stages of COPD due to absence of central obesity. Therefore "Metabolic Like Syndrome" should be coined in COPD where waist circumference is not an included.

\section{INTRODUCTION}

Chronic obstructive pulmonary disease (COPD) is a common, preventable and treatable disease that is characterized by persistent respiratory symptoms and airflow limitation that is due to airway and or alveolar abnormalities usually caused by significant exposure to noxious particles or gases ${ }^{1}$. The term chronic systemic inflammatory syndrome is proposed to take account of inflammatory nature of COPD and its co morbid conditions such as Metabolic syndrome (MetS). MetS has multiple risk factors that arises from insulin resistance accompanying abnormal adipose deposition and function. It is a risk factor for coronary heart disease, diabetes, fatty liver and several cancers. Obesity is seen in approximately $18 \%$ of patients with COPD and is far more common in early stages (stage-I and II) ${ }^{2}$.

Several studies ${ }^{3,4}$ from North America have shown a prevalence of metabolic syndrome (29\%-58\%)in COPD patients. Tanni et $\mathrm{al}^{5}$ reported that Mets was $36 \%$ in COPD patients. Indian data on the prevalence of MetS or its components in COPD are sparse. Dave et $\mathrm{l}^{6}$, reported MetS in $42 \%$ COPD cases.

The aim of this study was to investigate the prevalence of metabolic and metabolic like syndrome in stable COPD patients.

\section{METHODS}

This prospective study was conducted in 67 COPD patients attending the Department of Tuberculosis and Respiratory Diseases, G.S.V.M. Medical College, Kanpur from April- 2017 to March -2018.

\section{INCLUSION CRITERIA :}

- Stable COPD Patients.

\section{EXCLUSION CRITERIA :}

- Other respiratory diseases such as pulmonary tuberc ulosis, bronchial asthma, interstitial lung diseases, obstructive sleep apnea and lung cancer.
- Known case of Ischemic heart disease and chronic renal failure.

- Unstable COPD patients with acute exacerbation.

- Patients attending hospital with cough and breathles sness were evaluated for COPD as per GOLD-2017. All routine blood investigations including complete lipid profile and plasma glucose estimation (FBS \& OGTT) were done. Spirometry with reversibility was performed.

METABOLIC SYNDROME DEFINED AS PER NEW INTERNA TIONAL DIABETES FEDERATION IDF DEFINITION (IDF) ${ }^{7}$ :

- Central obesity (defined as waist circumference $>90 \mathrm{~cm}$ for men and $>80 \mathrm{~cm}$ for women, with ethnicity specific values for other groups)

- Plus any two of the following four factors:

- Raised TG level: >150 mg/dl (1.7 mmol/L), or specific treatment for this lipid abnormality.

- Reduced HDL cholesterol: $<40 \mathrm{mg} / \mathrm{dl}$ in males and $<50$ $\mathrm{mg} / \mathrm{dl}$ in females, or specific treatment for this lipid abnormality.

- Raised blood pressure: systolic BP $\geq 130$ or diastolic BP 85 $\mathrm{mm} \mathrm{Hg}$, or treatment of previously diagnosed hyper tension.

- $\quad$ Raised fasting plasma glucose (FPG) $\geq 100 \mathrm{mg} / \mathrm{dl}(5.6$ $\mathrm{mmol} / \mathrm{L}$ ), or previously diagnosed type 2 diabetes.

- If FPG above $5.6 \mathrm{mmol} / \mathrm{L}$ or $100 \mathrm{mg} / \mathrm{dL}$, Oral Glucose Tolerance Test is strongly recommended but is not necessary to define presence of the syndrome.

\section{STATISTICAL ANALYSIS}

Performed using SPSS 22.0 software package and instat graphpad software. Variables were analyzed using student's t test, fisher exact test and chi square test and $p<0.05$ was considered significant.

\section{RESULTS}

Total 67 patients were included for final analysis after exclusion criteria. Mean age of patients was 58.11 \pm 9.99 years. Overall percentage of obese, overweight, normal weight and underweight were $31.3 \%, 23.9 \%, 29.8 \%$ and $14.9 \%$ Prevalence of Metabolic Syndrome in our study was $29.85 \%$. 
respectively. $50 \%$ female and $22.2 \%$ male were obese. Mean BMI of male was $24.33 \pm 6.64 \mathrm{~kg} / \mathrm{m}^{2}$ and mean BMI of study population was $26.22 \pm 7.22 \mathrm{~kg} / \mathrm{m}^{2}$. The mean waist circumference of male was $86.91 \pm 13.31 \mathrm{~cm}$ while in female it was $87.18 \pm 14.51 \mathrm{~cm}$.

Most parameters of lipid profile were deranged in study population. Among all parameters of lipid profile, raised triglyceride was found in majority of patients (69.4\%) followed by LDL (63.2\%) and total cholesterol (63.2\%). In female HDL was decreased in majority (58.3\%) followed by LDL (36.8\%) and total cholesterol (36.8\%).

Raised Fasting Blood Sugar (FBS) was more in female (54.5\%) than males (31.1\%). Overall $38.8 \%$ patients had raised FBS or on antidiabetic drugs previously. (Table-1)

Table-1: Comparision of various parameters between MetS and non-MetS COPD patients.

\begin{tabular}{|l|l|l|l|l|l|}
\hline Parameter & $\begin{array}{l}\text { COPD with metabolic } \\
\text { syndrome } \\
(\mathbf{n = 2 0})\end{array}$ & $\begin{array}{l}\text { COPD without metabolic } \\
\text { syndrome } \\
(\mathbf{n = 4 7 )}\end{array}$ & $\begin{array}{l}\text { Name of test } \\
\text { (student test) }\end{array}$ & p value & $\begin{array}{l}\text { Significant/ } \\
\text { Non-significant }\end{array}$ \\
\hline Waist circumference & $101 \pm 11.17$ & $81.30 \pm 10.86$ & 2.0047 & 0.329 & Not significant \\
\hline TG & $202.26 \pm 97.72$ & $140.86 \pm 94.81$ & 2.0287 & 0.41 & Not significant \\
\hline HDL & $50.26 \pm 12.12$ & $54.77 \pm 12.76$ & 2.0094 & 0.592 & Not significant \\
\hline Fasting blood sugar & $133.22 \pm 21.06$ & $99.39 \pm 20.06$ & 2.0223 & 0.381 & Not significant \\
\hline Systolic BP & $148.09 \pm 29.31$ & $126.41 \pm 15.34$ & 2.0527 & 0.0001 & Significant \\
\hline
\end{tabular}

Metabolic syndrome was most common in GOLD stage two (47.06\%). (Table-2)

Table-2

\begin{tabular}{|c|c|c|c|c|c|}
\hline $\begin{array}{l}\text { Gold } \\
\text { Stage }\end{array}$ & \begin{tabular}{|l|} 
Total \\
Patients
\end{tabular} & & & $\begin{array}{l}\text { Metabolic } \\
\text { Syndrome }\end{array}$ & Total \\
\hline \multirow[t]{2}{*}{ I } & \multirow[t]{2}{*}{5} & Male & 3 & 1 & \multirow[t]{2}{*}{$2(40 \%)$} \\
\hline & & Female & 2 & 1 & \\
\hline \multirow[t]{2}{*}{ II } & \multirow[t]{2}{*}{17} & Male & 14 & 6 & \multirow[t]{2}{*}{$8(47.06 \%)$} \\
\hline & & Female & 3 & 2 & \\
\hline \multirow[t]{2}{*}{ III } & \multirow[t]{2}{*}{35} & Male & 22 & 4 & \multirow[t]{2}{*}{$9(25.71 \%)$} \\
\hline & & Female & 13 & 5 & \\
\hline \multirow[t]{2}{*}{ IV } & \multirow[t]{2}{*}{10} & Male & 6 & 0 & \multirow[t]{2}{*}{$1(10 \%)$} \\
\hline & & Female & 4 & 1 & \\
\hline TOTAL & $67(100 \%)$ & & & & $20(29.85 \%)$ \\
\hline
\end{tabular}

If we exclude central obesity as mandatory criteria for diagnosis of metabolic syndrome and have any two of four criteria (raised triglyceride, decreased HDL, raised blood pressure and raised fasting blood sugar) to diagnose metabolic like syndrome in stable COPD patients, then $42.2 \%$ male COPD patients and $81.8 \%$ female COPD patients have metabolic syndrome. (Table-3\&4)

Table-3

\begin{tabular}{|l|l|l|l|}
\hline Criteria Used & \multicolumn{3}{|l|}{$\begin{array}{l}\text { WAIST CIRCUMFERENCE CRITERIA NOT } \\
\text { INCLUDED }\end{array}$} \\
\cline { 2 - 4 } & $\begin{array}{l}\text { 2 out of } 4 \text { criteria used (Metabolic Like } \\
\text { Syndrome) }\end{array}$ \\
\hline Gold Stages & Male & Female & Total \\
\hline I & $2(66.6 \%)$ & $1(50 \%)$ & $3(60 \%)$ \\
\hline II & $5(35.7 \%)$ & $2(66.6 \%)$ & $7(41.2 \%)$ \\
\hline III & $9(40.9 \%)$ & $11(84.6 \%)$ & $20(57.1 \%)$ \\
\hline IV & $4(66.6 \%)$ & $3(75 \%)$ & $7(70 \%)$ \\
\hline TOTAL & $20(44.4 \%)$ & $17(77.3 \%)$ & $37(55.2 \%)$ \\
\hline
\end{tabular}

Table-4

\begin{tabular}{|l|l|l|l|l|}
\hline $\begin{array}{l}\text { GOLD } \\
\text { Stages }\end{array}$ & $\begin{array}{l}\text { Metabolic } \\
\text { Syndrome }\end{array}$ & $\begin{array}{l}\text { Metabolic Like } \\
\text { Syndrome }\end{array}$ & p value & $\begin{array}{l}\text { Significant/Non } \\
\text {-significant }\end{array}$ \\
\hline I & 2 & 3 & 1.00 & Not significant \\
\hline II & 8 & 7 & 0.72 & Not significant \\
\hline III & 9 & 20 & 0.01 & Significant \\
\hline IV & 1 & 7 & 0.02 & Significant \\
\hline
\end{tabular}

\section{DISCUSSION}

Prevalence of metabolic syndrome in our study was $29.85 \%$ ( $40.91 \%$ in female and $24.44 \%$ in male.). Metabolic syndrome was most common in GOLD stage-II $(47.06 \%)$ followed by stage-I (40\%) followed by stage-III (25.71\%) and it was only $10 \%$ in stage- IV. Henrik Watz et $\mathrm{al}^{8}$ reported metabolic syndrome in $47.5 \%$ patients with highest $(53 \%)$ in stage- II $50 \%$ in stage-I, $44 \%$ in stage-IV and $37 \%$ in stage-III. As per definition of metabolic syndrome, the central obesity is the basic prerequisite and less chance to find of metabolic syndrome in later stages of COPD due to absence of central obesity. Jesús Díez-Manglano et $\mathrm{al}^{9}$ found the overall prevalence of metabolic syndrome in COPD patients was $42.9 \%$, being more frequent in femcle $(59.5 \%)$.

Maximum patients of metabolic syndrome (45.5\%) were in stage-I \& II combined and only $22.2 \%$ of patients were in stage- III \& IV combined in our study. However, no significant variation was found in triglyceride levels, HDL levels, raised $\mathrm{BP}$ and raised FBS among various stages of COPD. It means that all parameters except central obesity were present in population and they were not affected by different GOLD stages.

If we exclude central obesity as mandatory criteria for diagnosis of MetS and have any two of four criteria (raised triglyceride, decreased HDL, raised blood pressure and raised fasting blood sugar) to diagnose, then $42.2 \%$ male COPD and $81.8 \%$ female COPD (overall 55.2\%) have metabolic like syndrome.

\section{CONCLUSION}

Advanced COPD patients do not have central obesity but they have other criteria fulfilling metabolic syndrome. So definition of metabolic syndrome should be reviewed for COPD patients and for other diseases with loss of fat and muscles mass. In other words central obesity should not be mandatory criteria in COPD.

\section{REFERENCES:}

. Global Initiative for Chronic Obstructive Lung Disease (GOLD). GOLD 2017 global strategy for the diagnosis, management, and prevention of chronic obstructive pulmonary disease, 2017 report.

2. Steuten LM, Creutzberg EC, Vrijhoef HJ, Wouters EF. COPD as a multicomponent disease: inventory of dyspnoea, underweight, obesity and fat free mass depletion in primary care. Pri Care Resp J. 2006 Apr 1;15(2):8491.

3. Park SK, Larson JL. Metabolic syndrome and associated factors in people with chronic obstructive pulmonary disease. West J Nursing Res. 2014 May;36(5):620-42.

4. Poulain M, Doucet M, Drapeau V, Fournier G, Tremblay A, Poirier $P$, et al. Metabolic and inflammatory profile in obese patients with chronic obstructive pulmonary disease. Chronic Resp Dis. 2008 Feb;5(1):35-41.

5. Tanni SE, Zamuner AT, Coelho LS, Vale SA, Godoy I, Paiva SA. Are metabolic syndrome and its components associated with 5-year mortality in chronic obstructive pupmonary disease patients?. Metab Syndrome Related Disord. 2015 Feb 1;13(1):52-4

6. Lopez AD, Shibuya K, Rao C, Mathers CD, Hansell AL, Held LS, et al. Chronic obstructive pulmonary disease: current burden and future projections. Euro Res J. 2006 Feb 1;27(2):397-412.

7. Zimmet P, Magliano D, Matsuzawa Y, Alberti G, Shaw J. The metabolic syndrome: a global public health problem and a new definition. J atheroscler thrombosis. 2005; 12(6):295-300.

8. Henrik Watz, Benjamin Waschki, Anne Kirsten, Kai-Christian Mu"ller Gunther Kretschmar, Thorsten Meyer, Olaf Holz, HelgoMagnussen. The Metabolic Syndrome in Patients With Chronic Bronchitis and COPD. 2009 
CHEST; $136(4): 1039$

9. Jesús Díez Manglano,José Barquero-Romero, Pedro Almagro,F. Javier

Cabrera, Francisco López García, Lorena Montero, Joan B. Soriano. COPD

patients with and without metabolic syndrome: clinical and functional

differences. Internal and Emergncy Medicine. 2013;1-27 